\title{
An investigation of nucleation events in a coastal urban environment in the Southern Hemisphere
}

\author{
J. F. Mejía and L. Morawska \\ International Laboratory of Air Quality and Health, Queensland University of Technology, 2 George St, \\ Brisbane QLD 4001, Australia
}

Received: 22 October 2008 - Published in Atmos. Chem. Phys. Discuss.: 23 January 2008

Revised: 4 September 2009 - Accepted: 2 October 2009 - Published: 21 October 2009

\begin{abstract}
Ambient aerosols play an important role in atmospheric processes affecting the human and natural environments. They affect air quality, reduce visibility, and induce climate change by directly scattering and/or absorbing the incoming solar radiation (Charlson et al., 1992; Kim et al., 2006), or indirectly by acting as cloud condensation nuclei (Hobbs, 1993). Aerosol particles are emitted from a variety of anthropogenic and natural sources either directly into the atmosphere or as secondary particles by gas-to-particle formation process.

There is growing interest in studying and analysing the mechanisms of formation of secondary particles. The development of new instruments during the 1990s to measure the particle size distribution of nanoparticles $(<50 \mathrm{~nm})$ has enabled scientists to observe the formation and growth of new particles (see Kulmala et al. (2004) for review). Nucleation events, that is, the appearance of a mode below $25-30 \mathrm{~nm}$ in the particle number size distribution, known as "nucleation mode" (e.g. Dal Maso et al., 2007; Tunved et al., 2003), usually in very large numbers, have been observed around the world. For example, they have been reported in remote (e.g. Tunved et al., 2003), urban (e.g. Jeong et al., 2004; Zhang et al., 2004) and coastal areas (e.g. Vaattovaara et al., 2006) and at various latitudes in the upper troposphere and the lower stratosphere (Lee et al., 2003).

It has been shown that the probability of nucleation was increased by elevated sulphur dioxide $\left(\mathrm{SO}_{2}\right)$ concentrations (Stanier et al., 2004). This gas is mainly emitted from anthropogenic sources such as the combustion of sulphurcontaining fossil fuel (Stern, 2005). Therefore, aerosol nucleation in the atmosphere would be expected to be enhanced by human activities (see also Curtius (2006) for discussion). In urban air, morning nucleation events have been found to
\end{abstract}

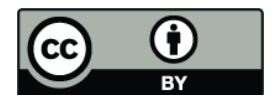

Correspondence to: L. Morawska (1.morawska@qut.edu.au) be consistent with peaks in traffic (Jeong et al., 2004). In contrast, in coastal environments, higher concentrations of nucleation mode particles have been observed during entries of clean air rather than of polluted air (O'Dowd et al., 2002). This is also confirmed by a Finish study (Spracklen et al., 2006), which found that particle concentrations in remote continental regions are dominated by nucleated particles whereas in polluted continental regions are dominated by primary particles.

This paper aims to analyse the frequency of and the atmospheric conditions favourable for nucleation events at coastal urban location in Brisbane, Australia, with a focus on the contribution of vehicle emissions. Monitoring was conducted during four campaigns of two weeks duration each, and a campaign of four weeks duration, covering a total period of 13 months. The objective was to investigate which meteorological conditions enhanced the probability of nucleation and to investigate any patterns in gaseous concentrations leading to the events to determine whether the local traffic was a major source of secondary particles in the study area.

\section{Methods}

\subsection{Description of the sampling area}

Figure 1 shows the sampling location. Monitoring was conducted at the southern end of Fisherman's Island, located at the mouth of the Brisbane River, approximately $22 \mathrm{~km} \mathrm{NE}$ of the central business district of Brisbane, on the southeast corner of the state of Queensland. The island is approximately $70 \mathrm{~m}$ East of the mainland, and connected to it by a road and rail corridor.

This site was selected because of the environmental diversity in the area. The sampling point was located between the road and railway line. The road and railway line follow

Published by Copernicus Publications on behalf of the European Geosciences Union. 


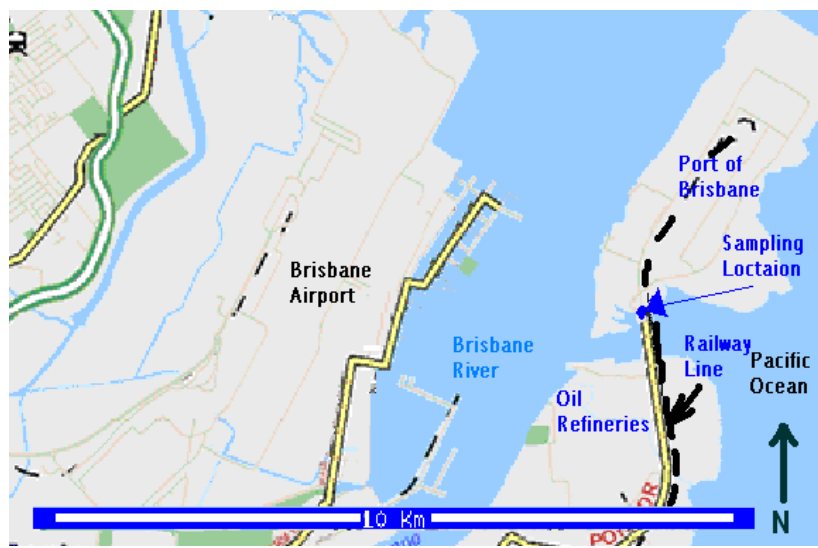

Fig. 1. Map of the sampling area.

a straight almost north-south path in the vicinity of the site. The sampling inlet was located in a flat area, $8 \mathrm{~m}$ east of the centre line of the road, $12 \mathrm{~m}$ west of the centre of the railway line and three metres above the ground surface. The site is surrounded by mangrove swamps to the north, and the Pacific Ocean to the east. An oil refinery is located in the south-western quadrant, with its closest point approximately $500 \mathrm{~m}$ from the sampling area. The mouth of the Brisbane River, on the west side of the sampling area, covers a width of approximately $4 \mathrm{~km}$ separating the site from the Brisbane airport and a small residential and industrial area. A seaport facility occupies most of the island, and is located approximately $1 \mathrm{~km}$ north of the site. Due to the freight activity in the area, traffic is dominated by diesel trucks.

\subsection{Description of the instruments and monitoring pro- cedure}

Particle size distribution in the range $14-800 \mathrm{~nm}$ was measured with a TSI 3934 Scanning Mobility Particle Sizer (SMPS). The SMPS consists of a TSI 3071A electrostatic classifier (EC) and a TSI 3010 condensation particle counter (CPC). The EC classifies particles according to size while the CPC counts the number of particles in each size channels. An interfacing computer controls the process of measurement and stores the data supplied by the counter. Monitoring was conducted continuously at five-minute intervals during the following campaigns: autumn 2006 (12 May-4 June), winter 2006 (18 August-3 September), spring 2006 (31 October-15 November), summer 2007 (12-31 January) and autumn 2007 (23 May-1 June).

Other air quality parameters measured were $\mathrm{NO}_{\mathrm{x}}$, and $\mathrm{SO}_{2} . \mathrm{NO}_{\mathrm{x}}$ concentration was measured with an Ecotech $9841 \mathrm{NO}_{\mathrm{x}}$ analyser, and $\mathrm{SO}_{2}$ concentration was measured with an Ecotech $9850 \mathrm{SO}_{2}$.

Meteorological conditions were measured with a Monitor Sensors MS1 portable weather station. The weather station monitored wind direction and speed as well as a range of other meteorological variables including temperature, relative humidity, atmospheric pressure and solar radiation intensity.

\subsection{Preparation of the database for analysis}

Generally, secondary particles are in the size range $<30 \mathrm{~nm}$ (Morawska et al., 2008). Therefore, the most important marker of a nucleation event is a significant increase in the concentration of these particles in the time series. Needless to say, this increase is also reflected by the appearance of a mode in this size range. Once a significant increase was identified, additional characteristics of the data such as traffic are examined to rule out primary particle sources. This procedure is similar to the one described by Stanier et al. (2004).

Due to limitations of the instrument, it was not possible to measure particles $<14 \mathrm{~nm}$ although the majority of these particles were expected to have formed below this limit. Therefore, it was assumed that the new particles were formed much earlier and grew principally by condensation mechanisms reaching a measureable size. Although losses due to coagulation were expected, most of these losses were likely to occur through coagulation with particles above $50 \mathrm{~nm}$. Therefore, the appearance of a mode at $<30 \mathrm{~nm}$ indicated that a substantial number of new particles were formed allowing a significant fraction to grow to a detectable size. This means that nucleation events manifest themselves by an increase of particle number concentration in the $14-30 \mathrm{~nm}$ size range $\left(\mathrm{N}_{14-30}\right)$. The first step was to divide the size distribution into $14-30$, $30-50,50-100,100-300$ and $300-800 \mathrm{~nm}$ and to calculate the total concentration of particles in each size class through the general formula:

$N_{p-q}=\alpha \sum_{p}^{q} N\left(d_{p}\right)$

Where $N\left(d_{p}\right)$ is the number concentration in the size interval $d_{p}+\Delta d_{p}$ and $\alpha$ is a normalisation factor obtained from the equation:

$\alpha=\log _{10}\left(d_{p}+\Delta d_{p}\right)-\log _{10}\left(d_{p}\right)$

The SMPS data covered 64 channels per decade, evenly spaced in the logarithmic scale. Calculation of the log differences between consecutive size channels gave an average $\alpha$-value of 0.015625 .

\subsection{Data analysis techniques}

To identify the increase in the concentration of the $\mathrm{N}_{14-30}$, the difference between two successive observations was calculated. In other words, the first-ordered difference of the time series was obtained through the general equation:

$$
\nabla N_{p-q}(t)=N_{p-q}(t)-N_{p-q}(t-1)
$$


If $\nabla N_{p-q}(t)$ is positive, then it indicates that a nucleation event has likely occurred; if it is negative, then it indicates that particle loss has occurred due to growth by coagulation or condensation, or removal due to diffusion, dilution, evaporation or any other removal mechanism. To assist in the interpretation of the results, contour plots were added.

To identify the preconditions for nucleation process, atmospheric conditions during the events were recorded. In addition, hourly average $\mathrm{NO}, \mathrm{NO}_{2}$ and $\mathrm{SO}_{2}$ concentrations prior to and during the event were recorded and the differences were calculated. This was done to determine whether any of these gases were particle precursors in the study area. Also, wind direction data were divided into following wind sectors (in degrees clockwise from $\mathrm{N}$ ):

- Railway $\left(35^{\circ}-125^{\circ}\right)$

- Southern mangrove swamps $\left(125^{\circ}-185^{\circ}\right)$

- Refinery $\left(185^{\circ}-215^{\circ}\right)$

$-\operatorname{Road}\left(215^{\circ}-305^{\circ}\right)$

- Port $\left(305^{\circ}-35^{\circ}\right)$

The analysis was done to identify the sources contributing to nucleation.

\section{Results}

\subsection{Mean variation of number size distribution}

The diurnal patterns of mean variation in number size distribution in each of the different campaigns are shown in Fig. 2. The data were highly reliable ( $>95 \%$ in each campaign) and all outliers were removed before plotting the results. The patterns are in general different for each campaign although the two autumn patterns are very similar. Due to the length of the series, there is no enough evidence to conclude that there is seasonality in the patterns. In most cases, particle number peaks above $30 \mathrm{~nm}$. Peaks below $30 \mathrm{~nm}$ are observed in the winter campaign between 06:00 and 08:00 local time.

In both autumn campaigns, the majority of the particles are in the approximate range $30-120 \mathrm{~nm}$. Throughout the day, particle number peaks at around $50-70 \mathrm{~nm}$ reaching maximum concentrations between 12:00 and 15:00. High concentrations are also observed in the morning although they are lower than those in the early afternoon.

During the winter campaign, there is greater variation in number size distribution. The highest concentrations are found between 07:00 and 09:00 peaking at around 20-30 nm, and between 18:00 and 22:00, peaking at around 50-60 nm. During the morning peak, there is a high concentration in the ultrafine range thus indicating that the observed peak in the nuclei mode can be explained by increased emissions.

The spring campaign follows a similar pattern to the winter campaign although the peak concentrations are lower. A
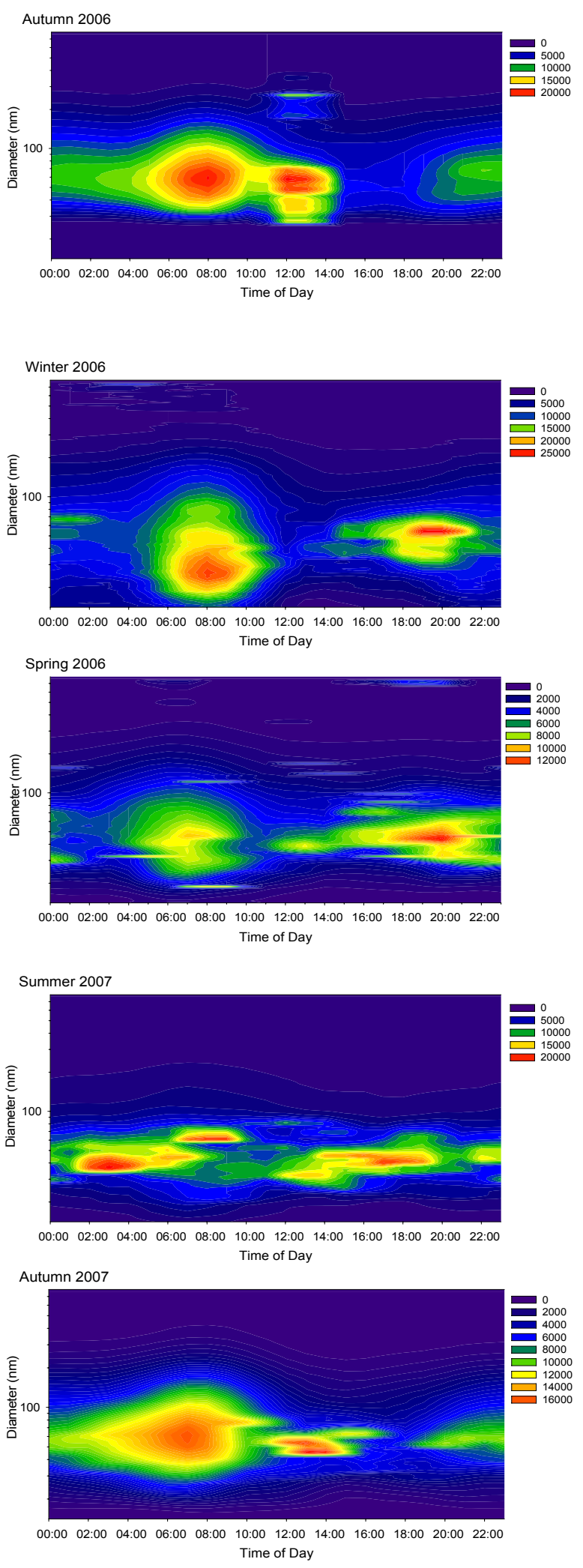

Fig. 2. Daily variation in number size distribution during each of the five measurement campaigns. The values are based on the hourly averages. The contours represent the concentrations expressed as $d N / d \log d P \mathrm{~cm}^{-3}$. 
small peak at about $20 \mathrm{~nm}$ is observed between 07:00 and 09:00, reaching maximum concentrations at 08:00. Although this peak is accompanied by high concentrations of larger ultrafine particles, this peak appears to have another source than the larger particles.

During the summer campaign, particle number peaks at around $35-45 \mathrm{~nm}$ between $02: 00$ and $04: 00,60-80 \mathrm{~nm}$ between 06:00 and 10:00, and 40-50 nm between 15:00 and 19:00. The maximum concentrations are comparable to those in the winter campaign although the pattern is visibly different.

To assist in the interpretation of the daily pattern, average particle number concentration of the $\mathrm{N}_{14-30}, \mathrm{~N}_{30-50}$, $\mathrm{N}_{50-100}, \mathrm{~N}_{100-300}$ and $\mathrm{N}_{300-800}$ were plotted against time of the day (Fig. 3). With the exception of the summer campaign, which shows fluctuations in number concentration throughout the day, all size classes follow similar daily patterns peaking at around 06:00-08:00. The highest values occur in winter and the lowest occur in spring and summer.

With the exception of winter, throughout the day the majority of particles are in the range 30-300 nm. During the autumn campaigns, the largest contributor to the particle number is the $\mathrm{N}_{50-100}$, followed by the $\mathrm{N}_{30-50}$ and $\mathrm{N}_{100-300}$ having similar contributions. The contribution of the $\mathrm{N}_{14-30}$ is visibly much lower, particularly in the autumn 2006 campaign.

During the winter campaign, the $\mathrm{N}_{14-30}$ is the maximum contributor to the particle number between 05:00 and 11:00, reaching a maximum of approximately $7.0 \times 10^{3} \mathrm{~cm}^{-3}$ at around 07:00. These peaks are characterised by relatively high number concentrations in the range $30-100 \mathrm{~nm}$, reaching concentrations of about $10.0 \times 10^{3} \mathrm{~cm}^{3}\left(\mathrm{~N}_{30-50}\right.$ and $\mathrm{N}_{50-100}$ combined). For most of the rest of the day, the maximum contributor is the $\mathrm{N}_{50-100}$, followed by the $\mathrm{N}_{30-50}$. Unlike the autumn campaigns, the $\mathrm{N}_{14-30}$ is a significant contributor to the particle number, reaching concentrations of about $3.0 \times 10^{3} \mathrm{~cm}^{-3}$.

In the spring, the maximum contributor is the $\mathrm{N}_{50-100}$ reaching maximum concentrations of $2.1 \times 10^{3} \mathrm{~cm}^{-3}$ between 05:00 and 08:00. The $\mathrm{N}_{30-50}$ is the second largest contributor reaching a maximum of about $1.9 \times 10^{3} \mathrm{~cm}^{-3}$ during these times. The corresponding $\mathrm{N}_{14-30}$ concentration is about $1.5 \times 10^{3} \mathrm{~cm}^{-3}$, becoming the third largest contributor, but declining sharply after these hours, down to less than $500 \mathrm{~cm}^{-3}$ at midday.

In summer, there are several fluctuations in number concentrations throughout the day, but the particle number is generally dominated by the $\mathrm{N}_{30-50}$ reaching their maxima at about $3.0 \times 10^{3} \mathrm{~cm}^{-3}$. For most of the day, the $\mathrm{N}_{50-100}$ remains the second largest contributor, with maximum concentrations of $2.5 \times 10^{3} \mathrm{~cm}^{-3}$ at around 06:00. The $\mathrm{N}_{14-30}$ is the third largest contributor, except between 08:00 and 09:00, where it is the largest with concentrations of about $2.0 \times 10^{3} \mathrm{~cm}^{-3}$, only slightly larger than the $\mathrm{N}_{50-100}$ concentration.
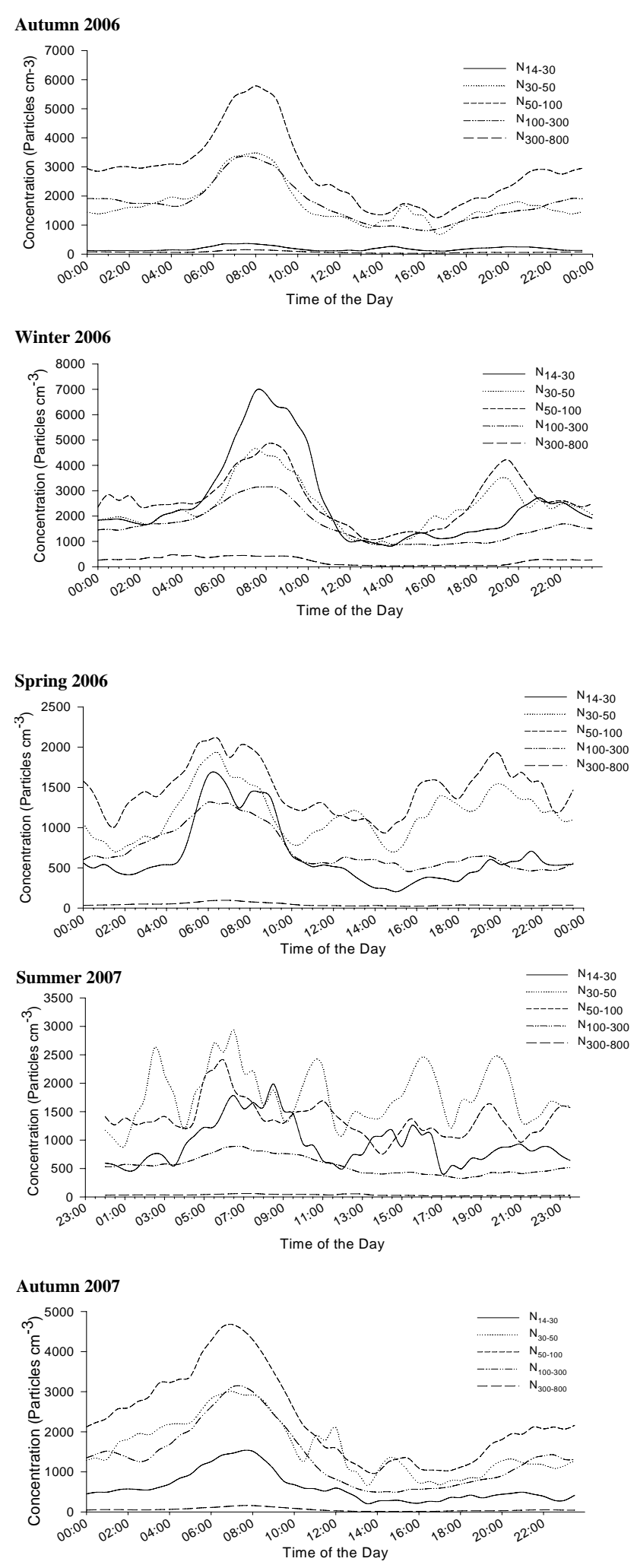

Fig. 3. Daily variation in particle number concentration of sizefractionated submicrometre particles. The figures are based on 30min averages. 
Table 1. Summary of conditions during nucleation events.

\begin{tabular}{|c|c|c|c|c|c|c|c|c|c|c|c|c|}
\hline \multirow[b]{2}{*}{ Date and Time } & \multirow{2}{*}{$\frac{\text { Temp }}{{ }^{\circ} \mathrm{C}}$} & \multirow{2}{*}{$\begin{array}{l}\text { Press } \\
\mathrm{KPa}\end{array}$} & \multirow{2}{*}{$\begin{array}{c}\text { Rel Hum } \\
\%\end{array}$} & \multirow{2}{*}{$\begin{array}{c}\text { Solar Rad } \\
\mathrm{W} \mathrm{m}^{-2}\end{array}$} & \multirow{2}{*}{$\begin{array}{c}\text { Wind Speed } \\
\mathrm{Km} \mathrm{h}^{-1}\end{array}$} & \multirow{2}{*}{$\begin{array}{l}\text { Wind } \\
\text { Sector }\end{array}$} & \multicolumn{3}{|c|}{$\mathrm{N}_{14-800}\left(\right.$ Particles $\left.\mathrm{cm}^{-3}\right)$} & \multicolumn{3}{|c|}{$\mathrm{N}_{14-30}\left(\right.$ Particles $\left.\mathrm{cm}^{-3}\right)$} \\
\hline & & & & & & & Before & During & Change & Before & During & Change \\
\hline 21-Aug-2006 10:10 & & & & & & & $3.17 \times 10^{4}$ & $1.44 \times 10^{4}$ & $-1.73 \times 10^{4}$ & $6.31 \times 10^{3}$ & $8.47 \times 10^{3}$ & $2.17 \times 10^{3}$ \\
\hline 24-Aug-2006 20:10 & 19.5 & 102 & 72.3 & 48 & 8.3 & Port & $4.23 \times 10^{4}$ & $1.81 \times 10^{4}$ & $-2.42 \times 10^{4}$ & $2.39 \times 10^{3}$ & $1.03 \times 10^{4}$ & $7.95 \times 10^{3}$ \\
\hline 30-Aug-2006 09:10 & 18.5 & 103 & 72.4 & 471 & 3.7 & Refinery & $2.52 \times 10^{4}$ & $2.04 \times 10^{4}$ & $-4.87 \times 10^{3}$ & $7.48 \times 10^{3}$ & $1.13 \times 10^{4}$ & $3.87 \times 10^{4}$ \\
\hline 30-Aug-2006 19:10 & 19.1 & 103 & 67.7 & 48 & 19.6 & Railway & 318 & $2.59 \times 10^{3}$ & $2.27 \times 10^{3}$ & 74 & $2.13 \times 10^{3}$ & $2.05 \times 10^{3}$ \\
\hline 31-Aug-2006 15:10 & 19.1 & 103 & 72.9 & 179 & 25.9 & Railway & 596 & $4.54 \times 10^{3}$ & $3.94 \times 10^{3}$ & 280 & $3.85 \times 10^{3}$ & $3.57 \times 10^{3}$ \\
\hline 2-Sep-2006 08:10 & 18.0 & 103 & 77.9 & 347 & 4.4 & Refinery & $8.00 \times 10^{3}$ & $1.34 \times 10^{4}$ & $5.36 \times 10^{3}$ & $2.29 \times 10^{4}$ & $7.85 \times 10^{3}$ & $5.55 \times 10^{3}$ \\
\hline 3-Sep-2006 10:10 & 21.6 & 103 & 60.8 & 741 & 7.4 & Port & $8.05 \times 10^{3}$ & $8.71 \times 10^{3}$ & 658 & $2.76 \times 10^{3}$ & $5.58 \times 10^{3}$ & $2.82 \times 10^{3}$ \\
\hline 7-Nov-2006 19:20 & 21.7 & 102 & 59.8 & 48 & 12.1 & Port & 949 & $6.92 \times 10^{4}$ & $6.82 \times 10^{4}$ & 240 & $6.67 \times 10^{4}$ & $6.64 \times 10^{4}$ \\
\hline 9-Nov-2006 12:20 & 21.0 & 102 & 62.6 & 708 & 21.0 & Railway & $3.26 \times 10^{4}$ & $1.58 \times 10^{3}$ & $-3.10 \times 10^{4}$ & 105 & $1.12 \times 10^{3}$ & $1.01 \times 10^{3}$ \\
\hline 12-Jan-2007 19:15 & 24.5 & 101 & 62.1 & 48 & 17.1 & Port & $1.95 \times 10^{3}$ & $6.35 \times 10^{3}$ & $-1.32 \times 10^{4}$ & 502 & $3.35 \times 10^{3}$ & $2.85 \times 10^{3}$ \\
\hline 14-Jan-2007 05:15 & 24.5 & 102 & 66.5 & 55 & 12.6 & Railway & 530 & $3.14 \times 10^{3}$ & $2.61 \times 10^{3}$ & 21.1 & $1.90 \times 10^{3}$ & $1.88 \times 10^{3}$ \\
\hline 14-Jan-2007 08:15 & 25.4 & 102 & 60.4 & 438 & 12.4 & Railway & $1.47 \times 10^{3}$ & $1.08 \times 10^{4}$ & $9.35 \times 10^{3}$ & 422 & $5.66 \times 10^{3}$ & $5.24 \times 10^{3}$ \\
\hline 14-Jan-2007 12:15 & 27.5 & 102 & 54.1 & 965 & 10.3 & Port & $2.18 \times 10^{3}$ & $2.02 \times 10^{3}$ & -159 & 367 & $1.26 \times 10^{3}$ & 897 \\
\hline 15-Jan-2007 04:15 & 24.4 & 102 & 57.6 & 47 & 5.3 & Railway & 439 & $9.37 \times 10^{3}$ & $8.93 \times 10^{3}$ & 19.1 & $5.51 \times 10^{3}$ & $5.49 \times 10^{3}$ \\
\hline 15-Jan-2007 14:15 & 27.5 & 102 & 51.7 & 876 & 15.9 & Railway & 948 & $2.16 \times 10^{4}$ & $2.07 \times 10^{4}$ & 311 & $1.25 \times 10^{4}$ & $1.22 \times 10^{4}$ \\
\hline 15-Jan-2007 18:15 & 25.7 & 102 & 55.7 & 75 & 16.8 & Railway & $1.03 \times 10^{3}$ & $1.73 \times 10^{3}$ & 703 & 59.0 & 956 & 897 \\
\hline 16-Jan-2007 8:15 & 25.0 & 102 & 53.3 & 630 & 10.9 & Railway & $3.61 \times 10^{3}$ & $6.84 \times 10^{3}$ & $3.24 \times 10^{3}$ & 845 & $4.37 \times 10^{3}$ & $3.53 \times 10^{3}$ \\
\hline 16-Jan-2007 21:15 & 24.7 & 102 & 60.0 & 46 & 21.5 & Railway & $2.28 \times 10^{4}$ & $5.17 \times 10^{3}$ & $-1.76 \times 10^{4}$ & $1.21 \times 10^{3}$ & $3.96 \times 10^{3}$ & $2.75 \times 10^{3}$ \\
\hline 17-Jan-2007 02:15 & 23.0 & 102 & 60.8 & 46 & 5.3 & Railway & 903 & $8.22 \times 10^{3}$ & $7.32 \times 10^{3}$ & 29.3 & $5.11 \times 10^{3}$ & $5.08 \times 10^{3}$ \\
\hline 17-Jan-2007 15:15 & 26.8 & 102 & 48.1 & 715 & 19.0 & Railway & 568 & $3.22 \times 10^{3}$ & $2.65 \times 10^{3}$ & 26.3 & $2.18 \times 10^{3}$ & $2.15 \times 10^{3}$ \\
\hline 18-Jan-2007 06:15 & 24.3 & 102 & 59.8 & 167 & 12.8 & Railway & $3.78 \times 10^{4}$ & $2.09 \times 10^{3}$ & $-3.57 \times 10^{4}$ & 19.1 & $1.07 \times 10^{3}$ & $1.05 \times 10^{3}$ \\
\hline 19-Jan-2007 13:15 & 26.2 & 102 & 55.3 & 916 & 13.7 & Railway & 300 & $5.27 \times 10^{3}$ & $4.97 \times 10^{3}$ & 9.05 & $3.17 \times 10^{3}$ & $3.16 \times 10^{3}$ \\
\hline 19-Jan-2007 15:15 & 26.4 & 102 & 53.0 & 746 & 18.0 & Railway & 837 & $1.41 \times 10^{3}$ & 569 & 99.5 & 975 & 876 \\
\hline 19-Jan-2007 20:15 & 24.6 & 102 & 56.8 & 46 & 14.4 & Railway & $7.91 \times 10^{4}$ & $4.59 \times 10^{3}$ & $-7.45 \times 10^{4}$ & $1.68 \times 10^{3}$ & $3.32 \times 10^{3}$ & $1.63 \times 10^{3}$ \\
\hline 25-Jan-2007 11:15 & 28.8 & 102 & 60.2 & 1063 & 14.5 & Port & $4.07 \times 10^{3}$ & $1.47 \times 10^{4}$ & $1.06 \times 10^{4}$ & $1.28 \times 10^{3}$ & $7.71 \times 103$ & $6.43 \times 10^{3}$ \\
\hline
\end{tabular}

To shed more light on the factors affecting the daily variation in particle number, average traffic numbers were plotted against time of the day (Fig. 4). The traffic pattern is more or less similar for the different seasons. There were problems of traffic data quality with the autumn 2006 campaign and therefore the results cannot be considered representative of the actual levels. Traffic volumes peak between 08:00 and 14:00, reaching levels between 120 vehicles $\mathrm{h}^{-1}$ in the winter and 180 vehicles $\mathrm{h}^{-1}$ in the autumn 2007. The traffic pattern reflects the level of commercial activity in the area, which is high during the normal working hours.

To further assist in the interpretation of the results, average wind directions for each campaign were plotted (Fig. 5). The graphs show that for both autumn campaign the wind exhibits similar daily patterns of variation. During the autumn and winter the wind originates predominantly from the south, in other words, from the refinery and mangrove swamps sectors. In spring, between 01:00 and 08:00, the wind originates from the road and port sectors. During the summer, for most of the day, the wind direction is from the railway sector.

\subsection{Nucleation events}

Table 1 provides a summary of the conditions observed during nucleation events and the increase in the $\mathrm{N}_{14-30}$. Nucleation events are defined as those where significant increases in the $\mathrm{N}_{14-30}$ are greater than more than $50 \%$ increase in total particle number. These events were fur- ther classified as "weak", "moderate" and "strong" following a criteria similar to the one used by Stanier et al. (2004): $d N_{14-30} / d t<4000 \mathrm{~cm}^{-3} \mathrm{~h}^{-1}$ was classified as weak, $d N_{14-30} / d t 4000-15000 \mathrm{~cm}^{-3} \mathrm{~h}^{-1}$ was classified as moderate, and $d N_{14-30} / d t>15000 \mathrm{~cm}^{-3}$ was classified as strong. In a similar manner to Stanier et al. (2004) $d N_{14-30} / d t$ is the nucleation rate but the number of nuclei clusters growing to a detectable size (i.e. above $14 \mathrm{~nm}$ ).

Figure 6 provides samples of the evolution in particle size distribution during the nucleation events. In order to provide as much insight of the particle evolution during these events, only the hours when nucleation was observed are shown. The events showed similar patterns during each campaign. Therefore, only two samples per campaign, randomly selected, are shown. No nucleation was observed during the autumn campaigns.

\subsubsection{Conditions that favoured nucleation}

The majority of the events took place in summer, followed by winter and two events in spring. No events were registered during the autumn campaigns. Increases in the concentration of the $\mathrm{N}_{14-30}$ did not necessarily result in a significant increase in total particle number. Air temperature ranged from $18.5^{\circ} \mathrm{C}$ to $28.8^{\circ} \mathrm{C}$ with an average of $23.7^{\circ} \mathrm{C}$. Solar radiation levels were high, ranging from $46 \mathrm{Wm}^{-2}$ to $1063 \mathrm{Wm}^{-2}$ and averaging $394 \mathrm{Wm}^{-2}$. Based on the observed data, a t-test was done to test the hypothesis that solar 
7882

J. F. Mejía and L. Morawska: An investigation of nucleation events in a coastal urban environment

Autumn 2006

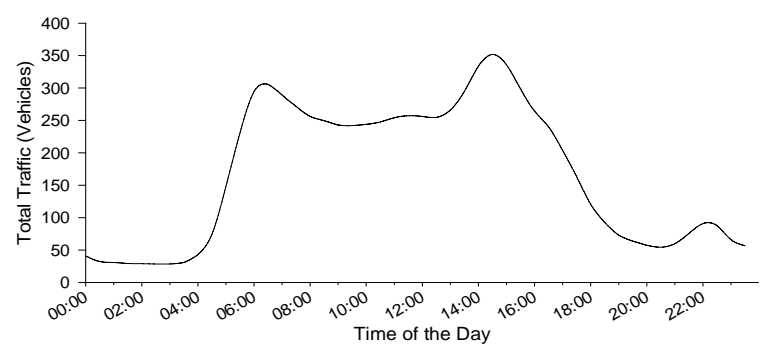

Winter 2006

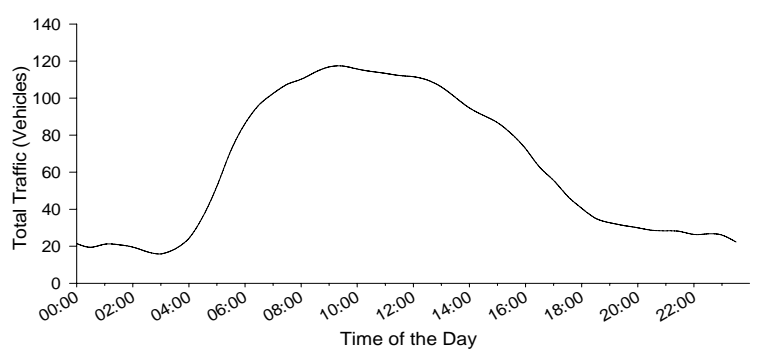

Spring 2006

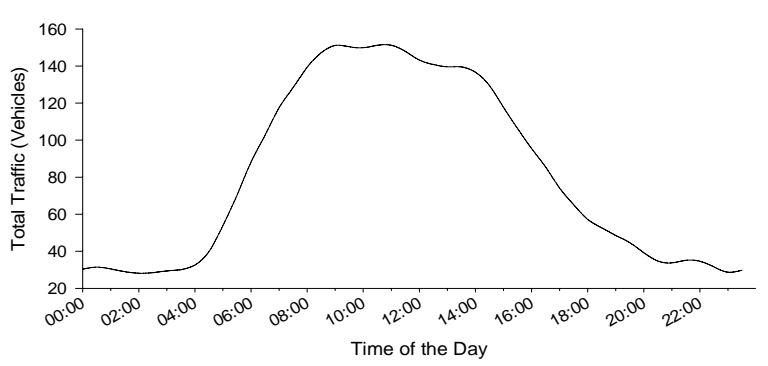

Summer 2007

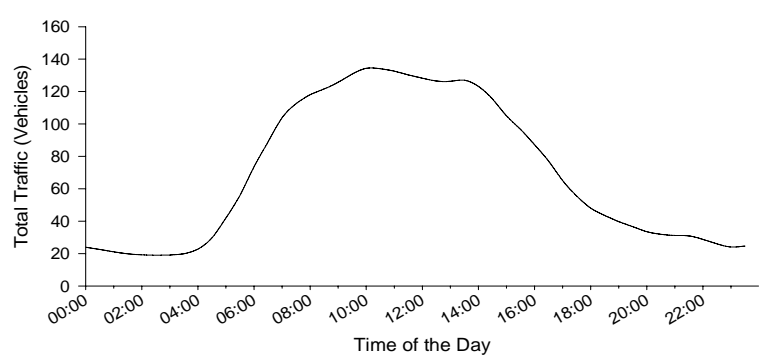

Autumn 2007

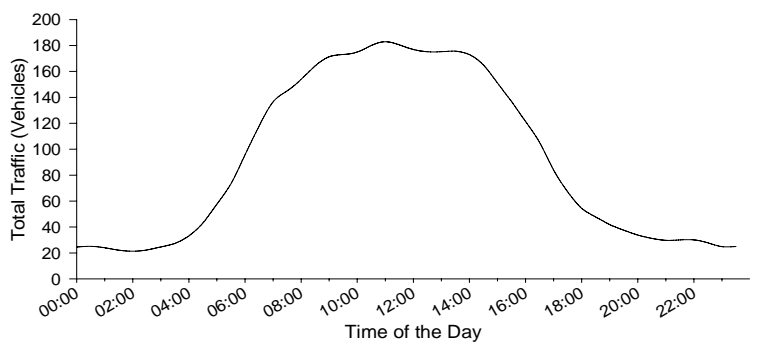

Fig. 4. Daily variation in traffic intensity levels during each campain.

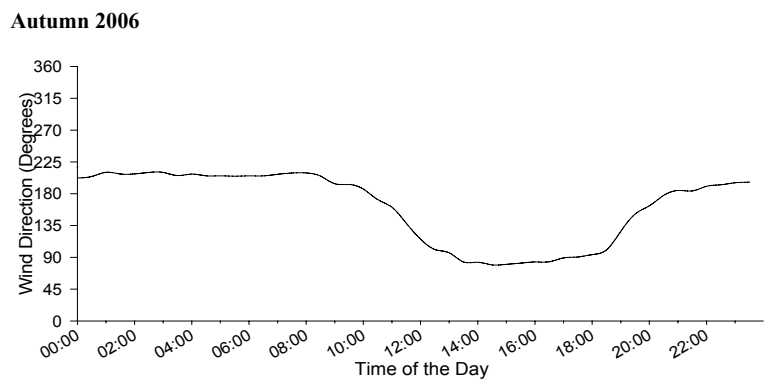

Winter 2006

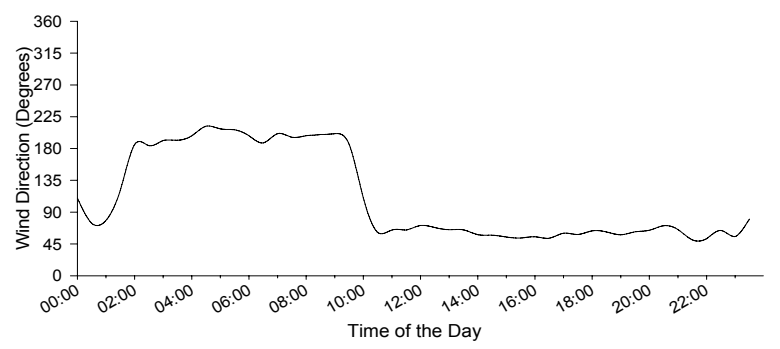

Spring 2006

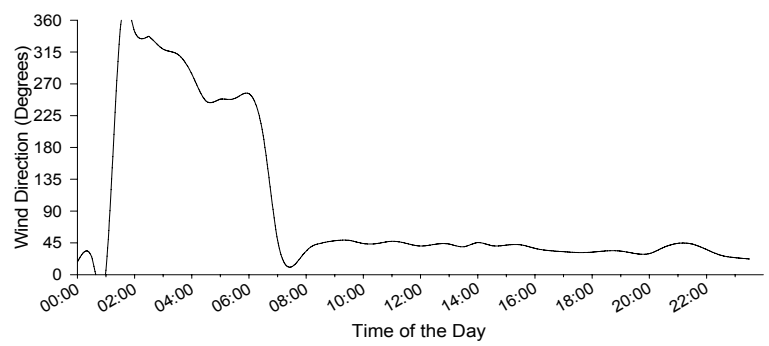

Summer 2007

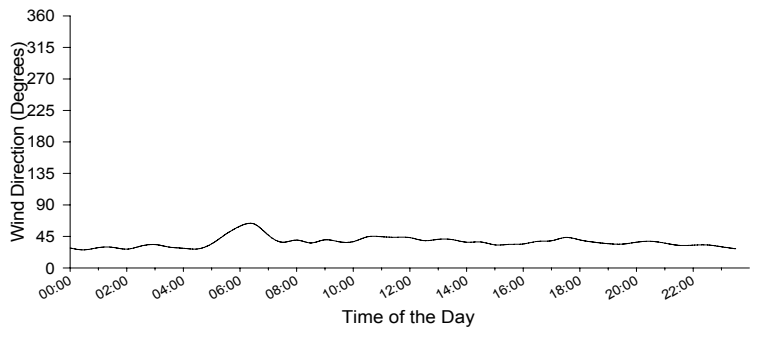

Autumn 2007

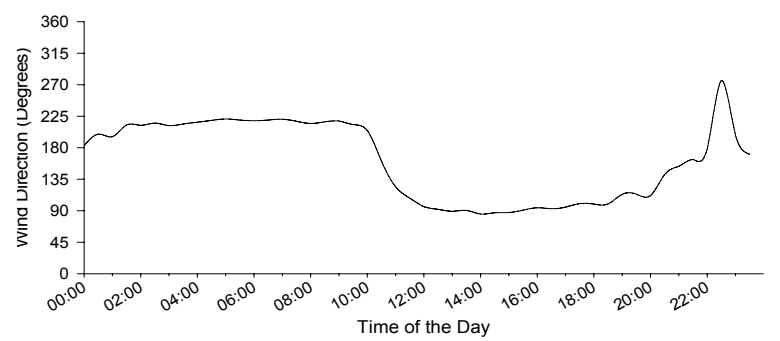

Fig. 5. Average daily variation in wind direction during each of the five measurement campaigns. The values were calculated from the average meridional $(\mathrm{N}-\mathrm{S})$ and zonal $(\mathrm{E}-\mathrm{W})$ wind components.

Atmos. Chem. Phys., 9, 7877-7888, 2009

www.atmos-chem-phys.net/9/7877/2009/ 
Spring 2006

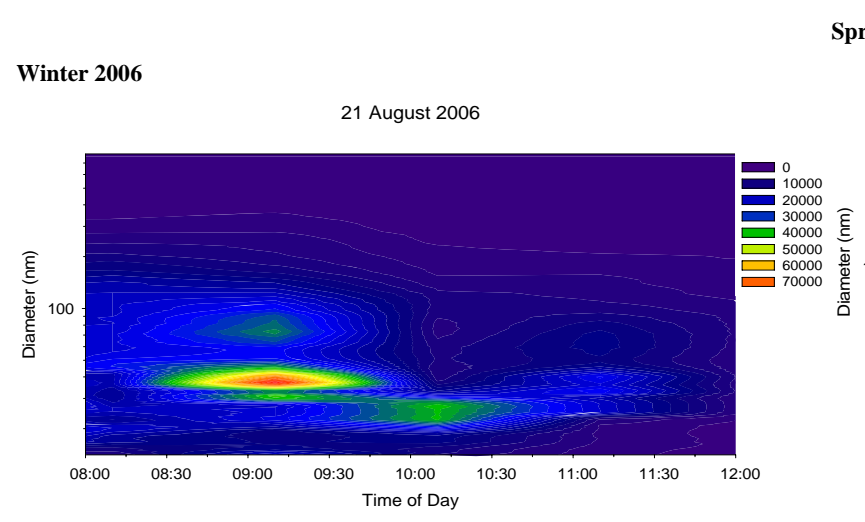

Winter 2006

30 August 2006

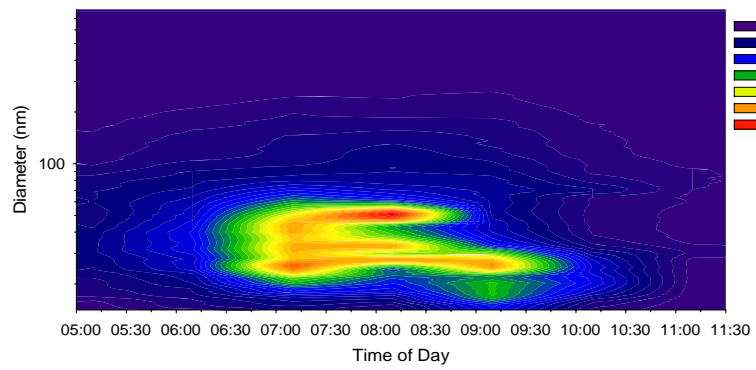

Summer 2006
7 November 2006

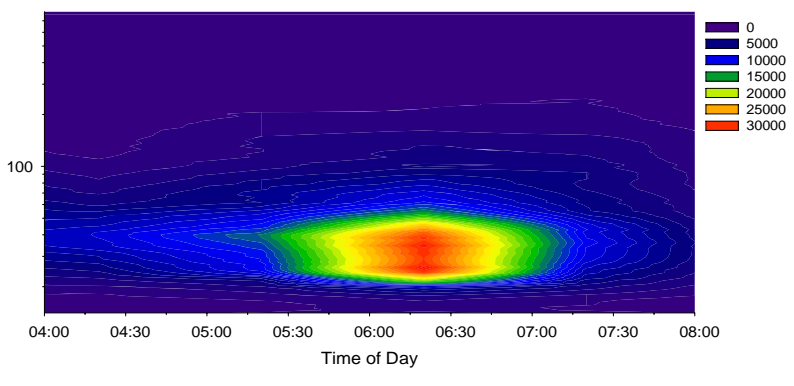

9 November 2006

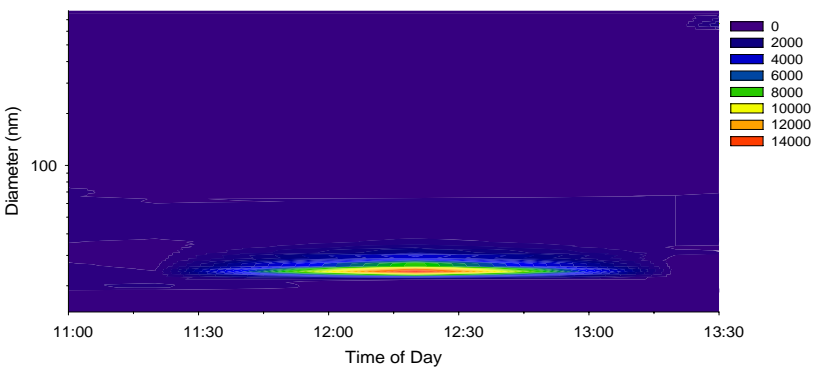

12 January 2007

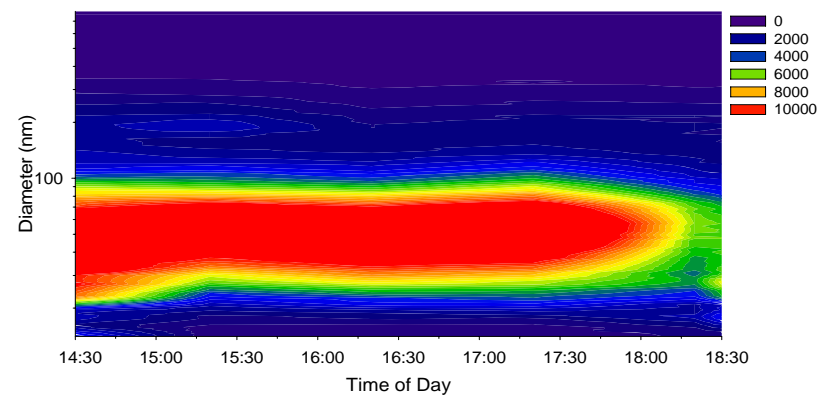

18 January 2007

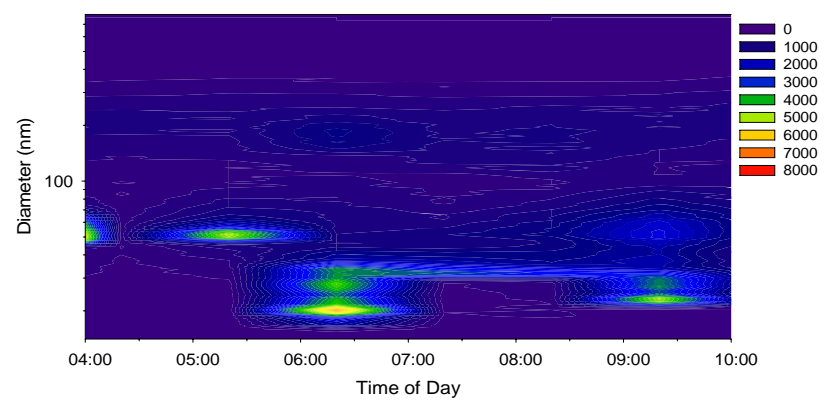

Fig. 6. Samples of observed nucleation events during the times they were observed in the different campaigns. The contours represent the particle concentrations expressed as $d N / d \log d P \mathrm{~cm}^{-3}$. 
radiation levels were significantly higher in summer than in winter. The test, however, proved that the difference was insignificant $(p=0.340)$. This is not surprising since sampling took place in a subtropical location, where the differences in sunlight and cloud cover between summer and winter are not as large as in more temperate climate. Relative humidity ranged from $51.7 \%$ to $77.9 \%$ averaging $70.7 \%$ in winter and $56.9 \%$ in summer. In this case, the t-test showed significant differences in relative humidity values $(p<0.01)$.

Sometimes, the change in total concentration was negative which indicates that nucleation events occur when the concentration of larger particles decreased. In most instances, the change in the $\mathrm{N}_{14-30}$ was greater than the change in total concentration, indicating that the events were correctly identified, in other words, the increases in $\mathrm{N}_{14-30}$ were no associated with significant increases in the concentration of the larger particles.

Table 2 shows the concentration of $\mathrm{NO}, \mathrm{NO}_{2}$ and $\mathrm{SO}_{2}$ before and during the events. No clear or dominant pattern is observed in the change of $\mathrm{NO}$ and $\mathrm{NO}_{2}$ concentrations. In most cases, $\mathrm{SO}_{2}$ concentrations, declined during the events. There were only a few exceptions, the most notable one in 19 January 2007 at 13:15, when the $\mathrm{SO}_{2}$ concentrations rose $12.9 \times 10^{-2} \mathrm{ppb}$ during the event.

\section{Discussion}

The size distribution of submicrometre particles in the size range $14-800 \mathrm{~nm}$ was examined in order to investigate the occurrence of nucleation events. The analysis was done by analysing the evolution of the size distribution during each day of the investigation, as well as the analysis of the time series of the concentration of size-fractionated particles using first-order differencing techniques.

Most nucleation events took place for the wind direction from the railway sector, in other words, when the wind moved towards the road. As mentioned earlier, traffic is dominated by diesel vehicles and therefore when the wind originates from the road the particle number is dominated by the $50-100 \mathrm{~nm}$ size fraction. Hitchins et al. (2000) found that when the wind moved towards the road, even at the closest point, the total particle concentration was similar to the background. Since passing of trains was rare, wind from the railway sector is dominated by the background and therefore this sector is associated with clean air masses. Sampling took place in a marine environment and therefore the influence of sea breeze is significant around the site, particularly at this sector, which was the closest to the ocean.

There were a few events associated with wind blowing from the port and the refinery sectors, and none from the road. This is indicative of long range transport. Several studies have shown that nucleation can occur more or less uniformly in air masses that extend several kilometres (e.g. Kulmala et al., 2001; O'Dowd et al., 2007). This means that newly formed particles can grow to a detectable size (i.e. $14 \mathrm{~nm}$ ) over several kilometres, despite dilution.

Figure 1 shows that the airport is located in the same sector as the road and therefore its influence on the data when the wind blew from this sector might appear clear at first glance. However, this effect was severely masked by the dominance of traffic emissions due to the much closer proximity between the road and sampling point. Furthermore, research has shown that particle number concentration and size distribution decrease with distance between the source and measurement location (e.g. Hitchins et al., 2000) and at about $300 \mathrm{~m}$ downwind from the source particle concentration is undistinguishable from background concentrations (Zhu et al., 2002a, b). Since the airport was located at a much greater distance to the site, about $4 \mathrm{~km}$, its contribution to the observed measurements when the wind blew from this sector was therefore negligible.

Even though the wind does not blow from the road during nucleation events, for all campaigns, the $\mathrm{N}_{14-30}$ peaked in the morning (Fig. 3) consistent with the peaks in traffic during the morning rush hours (Fig. 4) and the wind blowing close to the road sector $\left(215^{\circ}-305^{\circ}\right)$ (Fig. 5). Then it drops in concentration during the day as the wind moves away from this sector. This peak coincides with the peaks in the other size fractions and therefore reflects increased primary emissions.

Global radiation has been identified to influence new particle production (Boy and Kulmala, 2002; O'Dowd et al., 1999). Solar radiation levels are generally higher in summer and lower in winter and as a result American and European studies have found nucleation events to be more frequent in summer (e.g. Qian et al., 2007). Conversely, other studies have found that nucleation events are less frequent winter than in spring or autumn (e.g. Stanier et al., 2004) and sometimes they are even absent during the winter (Wehner and Wiedensohler, 2003). In contrast, a South Korean study found that nucleation events occurred more frequently in winter (Lee et al., 2008). The difference between the South Korean study and the European and American studies is that the South Korean study was done in a coastal environment whereas those in Europe and the USA were conducted in urban areas.

In the present study, although it took place in a coastal area, nucleation had a higher frequency in summer than in winter, which is more consistent with the urban studies above than with the coastal study in South Korea. Although this may reflect the high traffic activity at the site, thereby suggesting photochemical formation, the fact that none of them took place when the wind blew from the road indicates that they are not associated with traffic. These events were rarer in spring and absent in the autumn campaigns.

The statistical test showed that the difference in solar radiation levels during these events was almost the same between summer and winter. Furthermore, many of these events were observed at much lower radiation levels than those observed 
Table 2. Gaseous concentrations before and after nucleation events

\begin{tabular}{|c|c|c|c|c|c|c|c|c|c|}
\hline \multirow[t]{2}{*}{ Date and Time } & \multicolumn{3}{|c|}{ NO (pphm) } & \multicolumn{3}{|c|}{$\mathrm{NO}_{2}(\mathrm{pphm})$} & \multicolumn{3}{|c|}{$\mathrm{SO}_{2}\left(\times 10^{-2} \mathrm{ppb}\right)$} \\
\hline & Before & During & Change & Before & During & Change & Before & During & Change \\
\hline 21-Aug-2006 10:10 & 0.232 & 0.192 & -0.040 & 0.151 & 0.142 & -0.010 & 10.8 & 6.23 & -4.58 \\
\hline 24-Aug-2006 20:10 & 0.137 & 0.135 & -0.001 & 0.134 & 0.126 & -0.007 & 2.95 & 2.44 & -0.51 \\
\hline 30-Aug-2006 09:10 & 0.236 & 0.204 & -0.033 & 0.146 & 0.155 & 0.008 & 5.56 & 4.29 & -1.27 \\
\hline 30-Aug-2006 19:10 & 0.143 & 0.127 & -0.015 & 0.131 & 0.125 & -0.006 & 2.11 & 1.94 & -0.17 \\
\hline 31-Aug-2006 15:10 & 0.124 & 0.125 & 0.001 & 0.124 & 0.125 & 0.001 & 1.82 & 1.79 & -0.03 \\
\hline 2-Sep-2006 08:10 & 0.161 & 0.155 & -0.006 & 0.134 & 0.133 & 0.000 & 2.94 & 2.72 & -0.22 \\
\hline 3/09/2006 10:10 & 0.136 & 0.138 & 0.002 & 0.133 & 0.131 & -0.002 & 4.12 & 3.25 & -0.87 \\
\hline 7-Nov-2006 19:20 & 0.131 & 0.138 & 0.008 & 0.127 & 0.124 & -0.003 & 1.88 & 1.94 & 0.06 \\
\hline 9-Nov-2006 12:20 & 0.139 & 0.139 & 0.000 & 0.127 & 0.127 & 0.000 & 1.88 & 1.86 & -0.03 \\
\hline 12-Jan-2007 19:15 & 0.134 & 0.122 & -0.012 & 0.130 & 0.130 & -0.001 & 3.87 & 2.68 & -1.19 \\
\hline 14-Jan-2007 05:15 & 0.122 & 0.119 & -0.002 & 0.122 & 0.124 & 0.001 & 2.23 & 2.31 & 0.08 \\
\hline 14-Jan-2007 08:15 & 0.128 & 0.130 & 0.001 & 0.123 & 0.123 & 0.000 & 2.38 & 2.22 & -0.16 \\
\hline 14-Jan-2007 12:15 & 0.121 & 0.123 & 0.002 & 0.125 & 0.124 & -0.002 & 2.31 & 2.03 & -0.28 \\
\hline 15-Jan-2007 04:15 & 0.122 & 0.125 & 0.003 & 0.123 & 0.123 & 0.000 & 1.93 & 1.91 & -0.01 \\
\hline 15-Jan-2007 14:15 & 0.124 & 0.125 & 0.001 & 0.124 & 0.126 & 0.002 & 1.77 & 1.58 & -0.19 \\
\hline 15-Jan-2007 18:15 & 0.122 & 0.128 & 0.005 & 0.126 & 0.124 & -0.002 & 1.63 & 1.82 & 0.19 \\
\hline 16-Jan-2007 08:15 & 0.132 & 0.119 & -0.014 & 0.131 & 0.130 & -0.001 & 9.34 & 2.71 & -6.63 \\
\hline $16 / 01 / 200721: 15$ & 0.123 & 0.121 & -0.002 & 0.131 & 0.128 & -0.004 & 0.15 & 0.17 & 0.02 \\
\hline 17-Jan-2007 02:15 & 0.123 & 0.152 & 0.029 & 0.127 & 0.133 & 0.006 & 2.05 & 2.28 & 0.23 \\
\hline 17-Jan-2007 15:15 & 0.121 & 0.118 & -0.003 & 0.127 & 0.127 & 0.000 & 15.2 & 9.27 & -5.95 \\
\hline 18/01/2007 06:15 & 0.167 & 0.168 & 0.001 & 0.147 & 0.147 & 0.000 & 26.5 & 23.8 & -2.63 \\
\hline 19-Jan-2007 13:15 & 0.123 & 0.119 & -0.004 & 0.417 & 0.211 & -0.206 & 14.7 & 27.6 & 12.90 \\
\hline 19-Jan-2007 15:15 & 0.122 & 0.118 & -0.005 & 0.135 & 0.126 & -0.009 & 19.1 & 11.1 & -8.05 \\
\hline 19-Jan-2007 20:15 & 0.124 & 0.118 & -0.007 & 0.121 & 0.128 & 0.006 & 3.54 & 3.36 & -0.17 \\
\hline 25-Jan-2007 11:15 & 0.111 & 0.121 & 0.010 & 0.125 & 0.124 & -0.001 & & & \\
\hline
\end{tabular}

in East St. Louis (Qian et al., 2007). In that study, nucleation was observed when the median solar radiation intensity was $680 \mathrm{~W} \mathrm{~m}^{-2}$ and no nucleation events were observed at below $450 \mathrm{~W} \mathrm{~m}^{-2}$ (Qian et al., 2007). In the present investigation, nucleation events were observed even when solar radiation intensity was as low as $46 \mathrm{~W} \mathrm{~m}^{-2}$. This compares well with the conditions observed in coastal environments (e.g. Lee et al., 2008). The occurrence of new particle production depends not only on the presence of intense solar radiation but also on the properties of the present air mass (Wehner and Wiedensohler, 2003). Therefore, although the importance of solar radiation upon new particle formation cannot be dismissed, there are other forces influencing the process, for example, the type of environment.

This study found that new particle production took place at relative humidity values of around $50 \%$ to $80 \%$ and air temperatures of $18.0^{\circ} \mathrm{C}$ to around $29^{\circ} \mathrm{C}$. The relative humidity conditions for nucleation are similar to those reported by O'Dowd et al. (2002) whilst the temperature in this study are higher than those reported in that study. Micrometeorological processes promote an increase in surface vapour flux by providing additional water vapour, which increases the nucleation probability along with possible nucleation precursor species (O'Dowd et al., 2002). Similarly, increases in turbulent fluctuations in temperature and humidity can also significantly increase the probability of nucleation (Easter and Peters, 1994; Pirjola et al., 2000; Nilsson and Kulmala, 1998).

Figure 6 shows that the events were of very short duration, lasting a maximum of $4 \mathrm{~h}$. The typical "banana" shapes observed in different studies (e.g. Boy and Kulmala, 2002; Spracklen et al., 2006; Stanier et al., 2004) does not occur here. This means that the burst of $\mathrm{N}_{15-30}$ followed by growth was not observed and therefore these events were associated with air masses of local origin. Park et al. (2008) observed a similar phenomenon in the range $3-10 \mathrm{~nm}$ and hypothesized that this occurred because in the event nucleation and growth occurred above in the air and that subsequent vertical mixing caused the grown particles to reach the sampling point. They proposed this hypothesis after observing a gradual growth pattern only after particles larger than $10 \mathrm{~nm}$ had appeared. Although the lower size limit in our study was $14 \mathrm{~nm}$, this hypothesis could be applied to this study provided that a growth pattern would be observed in the range above $30 \mathrm{~nm}$. However, this did not occur. No increases in the number concentration of particles $>30 \mathrm{~nm}$ were observed after the events and the concentration of smaller particles 
dropped significantly after $2-4 \mathrm{~h}$. The analysis of the daily pattern of variation in size distribution and the concentration of size-fractionated particles indicates that the particle number is dominated by the range $50-100 \mathrm{~nm}$, which is consistent with the size distribution observed for diesel exhaust emissions (Morawska et al., 1998). This is not surprising since the site is dominated by diesel traffic and sampling took place very close to the road. The dominance of this size range has the effect of increasing the available surface area. The presence of a high particle surface area prevents nucleation due to diffusion of small particles and condensed material to the surface of larger particles (e.g. Friedlander et al., 1991). This led us to hypothesise that air masses associated with nucleation events mixed quickly with emissions from the road. As a result, nucleation events were rare and of very short duration.

Particle number concentration was higher in winter caused by different meteorological conditions reducing the available volume of air for their dispersion. The peak in their concentrations, with the exception of summer, occurred at around 06:00-09:00 consistent with increases in traffic volumes. Although traffic levels peak at around midday, particle number is lower than during the morning rush.

It was observed that often the formation of new particles was accompanied by decreases in the concentration of larger particles. This is shown by the negative change in total concentration during the events even though the $\mathrm{N}_{14-30}$ increases significantly. Spracklen et al. (2006) showed that significant reductions in primary particle emissions may lead to an increase in total particle concentration because of the coupling between particle surface area and the rate of new particle formation. In the present study, new particle formation did not necessarily increase the total particle concentration.

Gaseous sulphuric acid has been identified as a key compound for the formation and growth of new particles and is formed by the reaction of $\mathrm{SO}_{2}$ with the hydroxyl radical (Kerminen et al., 2004). Urban (e.g. Qian et al., 2007; Woo et al., 2001) and coastal studies (Lee et al., 2008) found that $\mathrm{SO}_{2}$ concentrations increased during nucleation events. In contrast, this study found that with only some notable exceptions, $\mathrm{SO}_{2}$ concentrations declined during the events. No reasonable explanation can be found for this discrepancy except that in the present study nucleation events were associated with cleaner air masses, or that the $\mathrm{SO}_{2}$ is being consumed during nucleation.

\section{Summary and conclusions}

The evolution of particle size distribution in the range 14$800 \mathrm{~nm}$ was analysed in order to determine the frequency of nucleation events during four campaigns of two weeks duration and one campaign of four weeks, covering a total period of 13 months.
This study found that nucleation events were rare and of very short duration and did not contribute to large concentrations. The majority of the events took place in summer. There were no events during the autumn campaigns and events in winter were more frequent than in spring. These events occurred randomly independent of time of the day although they were more frequent during the daylight hours. During these events, there was no significant difference in solar radiation levels. Therefore, the differences in occurrences of nucleation between summer and winter are not explained by differences in solar radiation levels.

In many cases, the formation of new particles did result in significant reductions in the total particle concentration. This is because there are differences in size distributions and number concentrations between the road sector and the railway sector. The road sector is dominated by diesel traffic and therefore there is a much higher concentration of larger particles whereas the railway sector is mostly associated with the background emissions largely influenced by sea breeze.

Nucleation occurred in most cases when the wind originated from the railway sector followed by the port sector. Trains passing by were a rare occurrence and therefore train emissions had little influence in railway sector. No nucleation was observed when the wind originated from the road. Therefore, nucleation events were associated with and cleaner air masses of local origin that mixed quickly with road emissions after the events, causing them to be shortlived. This was because more polluted air from the road was associated with direct emissions of larger particles providing a greater available surface area for condensation, thus reducing the probability of nucleation from this sector.

$\mathrm{NO}$ and $\mathrm{NO}_{2}$ did not play any role in nucleation. There was no clear pattern of change in their concentrations during nucleation events. In contrast, in most cases, $\mathrm{SO}_{2}$ concentrations declined during the events. The only plausible explanation is that nucleation was favoured by cleaner air conditions or that $\mathrm{SO}_{2}$ was being consumed during nucleation. However, there were a few occasions when $\mathrm{SO}_{2}$ increased therefore its role in nucleation is not very clear.

Acknowledgements. This project was supported by the Australian Research Council and Queensland Transport through Linkage Grant LP0882544 and also by the Port of Brisbane Corporation. The authors wish to extend their thanks to Randall Fletcher (Queensland Transport) and Brad Kitchen (Port of Brisbane Corporation) for their invaluable help and advice and for supporting this research,, as well as to Graham Johnson, of the International Laboratory of Air Quality and Health (ILAQH), for supplying the data and his useful comments in the preparation of this paper.

Edited by: K. Hämeri 


\section{References}

Boy, M. and Kulmala, M.: Nucleation events in the continental boundary layer: influence of physical and meteorological parameters. Atmos. Chem. Phys., 2, 1-16, 2002.

Charlson, R. J., Schwartz, S. E., Hales, J. M., Cess, R. D., Coakley Jr., J. A., Hansen, J. E., and Hofmann, D. J.: Climate forcing by anthropogenic aerosols, Science, 255, 423-430, 1992.

Curtius, J.: Nucleation of atmospheric aerosols, Physique, 7, 10271045, 2006.

Dal Maso, M., Sogacheva, L., Aalto, P. P., Riipinen, I., Komppula, M., Tunved, P., Korhonen, L., Suur-Uski, V., Hirsikko, A., Kurten, T., Kerminen, V.-M., Lihavainen, H., Viisanen, Y., Hansson, H.-C., and Kulmala, M.: Aerosol size distribution measurements at four Nordic field stations: identification, analysis and trajectory analysis of new particle formation bursts. 59, 350-361, 2007.

Easter, R. C. and Peters, L. K.: Binary homogeneous nucleation: Temperature and relative humidity fluctuations, nonlinearity, and aspects of new particle production in the atmosphere, J. Appl. Meteorol., 33, 775-784, 1994.

Friedlander, S. K., Koch, W. and Main, H. H.: Scavenging of a coagulating fine aerosol by a coarse particle model, J. Aerosol Sci., 22, 1-8, 1991.

Hitchins, J., Morawska, L., Wolff, R., and Gilbert, D.: Concentrations of submicrometre particles from vehicle emissions near a major road, Atmos. Environ., 34, 51-59, 2000.

Hobbs, P. V. (ed.): Cloud interactions, in: Aerosol-cloud-climate interactions, San Diego, California, USA, Academic Press, p. 233, 1993.

Jeong, C.-H., Hopke, P. K., Chalupa, D., and Utell, M.: Characteristics of Nucleation and Growth Events of Ultrafine Particles Measured in Rochester, NY, USA, Environ. Sci. Technol., 37, 1933-1940, 2004.

Kerminen, V. M., Lehtinen, K. J., Anttila, T. and Kulmala, M.: Dynamics of atmospheric nucleation mode particles: a time scale analysis. Chem. Phys. Meteorol., 56, 2004.

Kim, J., Yoon, S.-C., Kim, S.-W., Brechtel, F., Jefferson, A., Dutton, E. G., Bower, K. N., Cliff, S., and Schauer, J. J.: Chemical apportionment of shortwave direct aerosol radiative forcing at the Gosan super-site, Korea during ACE-Asia, Atmos. Environ., 40, 6718-6729, 2006.

Kulmala, M., Maso, M. D., Makela, J. M., Pirjola, L., Vakeva, M., Aalto, P., Miikkulainen, P., Hameri, K. and O'Dowd, C. D.: On the formation, growth and composition of nucleation mode particles, Chem. Phys. Meteorol., 53, 479-490, 2001.

Kulmala, M., Vehkamaki, H., Petaja, T., Dal Maso, M., Lauri, A., Kerminen, V. M., Birmili, W., and McMurry, P. H. () Formation and growth rates of ultrafine atmospheric particles: a review of observations, J. Aerosol Sci., 35, 143-176, 2004.

Lee, S.-H., Reeves, J. M., Wilson, J. C., Hunton, D. E., Viggiano, A. A., Miller, T. M., Ballenthin, J. O. and Lait, L. R. (2003) Particle formation by ion nucleation in the upper tropospher and lower stratosphere. Science, 301, 1886-1889.

Lee, Y.-G., Lee, H.-W., Kim, M.-S., Choi, C. Y., and Kim, J.: Characteristics of particle formation events in the coastal region of Korea in 2005, Atmos. Environ., 42, 3729-3739, 2008.

Morawska, L., Ristovski, Z., Jayaratne, E. R., Keogh, D. U., and Ling, X.: Ambient nano and ultrafine particles from motor vehicle emissions: Characteristics, ambient processing and impli- cations on human exposure. Atmos. Environ., 42, 8113-8138, 2008.

Nilsson, E. D. and Kulmala, M.: The potential for atmospheric mixing processes to enhance the binary nucleation rate, J. Geophys. Res., 103, 1381-1389, 1998.

O’Dowd, C. D., McFiggans, G., Creasey, D. J., Pirjola, L., Hoell, C., Smith, M. H., Allan, B. J., Plane, J. M. C., Heard, D. E., Lee, J. D., Pilling, M. J., and Kulmala, M.: On the photochemical production of new particles in the coastal boundary layer, Geophys. Res. Lett., 26, 1707-1710, 1999.

O’Dowd, C. D., Yoon, K. Y., Junkerman, W., Aalto, P., Kulmala, M., Lihavainen, H., and Viisanen, Y.: Airborne measurements of nucleation mode particles I: coastal nucleation and growth rates, Atmos. Chem. Phys., 7, 1491-1501, 2007.

O’Dowd, C. D., Hämeri, K., Mäkelä, J., Väkeva, M., Aalto, P., de Leeuw, G. K., Gerard J., Becker, E., Hansson, H.-C., Allen, A. G., Harrison, R. M., Berresheim, H., Kleefeld, C., Geever, M., Jennings, S. G. and Kulmala, M. (2002) Coastal new particle formation: environmental conditions and aerosol physicochemical characteristics during nucleation bursts, J. Geophys. Res., 107, PAR12.1-PAR12.17

Park, K., Park, J. Y., Kwak, J.-H., Cho, G. N., and Kim, J.-S.: Seasonal and diurnal variations of ultrafine particle concentration in urban Gwangju, Korea: Observation of ultrafine particle events, Atmos. Environ., 42, 788-799, 2008.

Pirjola, L., O'Dowd, C. D., Brooks, I. M. and Kulmala, M.: Can new particle formation occur in the clean marine boundary layer? J. Geophys. Res., 105, 26531-26546,, 2000.

Qian, S., Sakurai, H., and McMurry, P. H.: Characteristics of regional nucleation events in urban East St. Louis, Atmos. Environ., 41, 4119-4127, 2007.

Spracklen, D. V., Carslaw, K. S., Kulmala, M., Kerminen, V.-M., Mann, G. W., and Sihto, S.-L.: The contribution of boundary layer nucleation events to total particle concentrations on regional and global scales. Atmos. Chem. Phys., 6, 5631-5648, 2006.

Stanier, C. O., Khlystov, A. Y. and Pandis, S. N.: Nucleation Events During the Pittsburgh Air Quality Study: Description and Relation to Key Meteorological, Gas Phase, and Aerosol Parameters, Aerosol Sci. Technol., 38, 253-264, 2004.

Stern, D. I.: Global sulfur emissions from 1850 to 2000, Chemosphere, 58, 163-175, 2005.

Tunved, P. H. C., H., Kulmala, M., Aalto, P., Viisanen, Y., Karlsson, H., Kristensson, A., and Swietlicki, E.: One year boundary layer aerosol size distribution data from five nordic background stations, Atmos. Chem. Phys., 3, 2183-2205, 2003.

Vaattovaara, P., Huttunen, P. E., Yoon, Y. J., Joutsensaari, J., Lehtinen, K. J., O'Dowd, C. D., and Laaksonen, A.: The composition of nucleation and Aitken modes particles during coastal nucleation events: evidence for marine secondary contribution. Atmos. Chem. Phys., 6, 4601-4616, 2006, http://www.atmos-chem-phys.net/6/4601/2006/.

Wehner, B. and Wiedensohler, A.: Long term measurements of submicrometer urban aerosols: statistical analysis for correlations with meteorological conditions and trace gases, Atmos. Chem. Phys., 3, 867-879, 2003, http://www.atmos-chem-phys.net/3/867/2003/.

Woo, K. S., Chen, D. R., Pui, D. Y. H., and McMurry, P. H.: Measurement of Atlanta Aerosol Size Distributions: Observation of 
ultrafine particle events, Aerosol Sci. Technol., 34, 75-87, 2001. Zhang, Q., Stanier, C. O., Canagaratna, M. R., Jayne, J. T., Worsnop, D. R., Pandis, S. N., and Jimenez, J. L.: Insights into the Chemistry of New Particle Formation and Growth Events in Pittsburgh Based on Aerosol Mass Spectrometry, Environ. Sci. Technol., 38, 4797-4809, 2004.

Zhu, Y., Hinds, W. C., Kim, S., Shen, S., and Sioutas, C.: Study of ultrafine particles near a major highway with heavy-duty diesel traffic. Atmos. Environ., 36, 4323-4335, 2002a.
Zhu, Y., Hinds, W. C., Kim, S., and Sioutas, C.: Concentration and size distribution of ultrafine particles near a major highway, J. Air Waste Manage. Assoc., 52, 1032-1042, 2002 b. 